\title{
The study of angiotensin converting enzyme isolation from crossbred rabbit lung and enzyme storage capacity in frozen conditions
}

\author{
${ }^{1 *}$ Nguyen, V.M., ${ }^{1}$ Tran, T.T. and ${ }^{2 *}$ Vo, H.N. \\ ${ }^{1}$ College of Agriculture, Can Tho University, Campus 2, 3/2 street, Ninh Kieu District, Can Tho City, \\ Vietnam. \\ ${ }^{2}$ Department of Science and Technology of Vinh Long province, 111 Nguyen Hue street, Ward 2, Vinh \\ Long City, Vinh Long Province, Vietnam.
}

\author{
Article history: \\ Received: 2 January 2020 \\ Received in revised form: 29 \\ February 2020 \\ Accepted: 3 March 2020 \\ Available Online: 26 March \\ 2020
}

\section{Keywords:}

Ammonium sulfate,

Angiotensin converting enzyme (ACE),

Activity,

Crossbred rabbit lung,

Extract,

Frozen

DOI:

https://doi.org/10.26656/fr.2017.4(4).011

\begin{abstract}
The study was carried out to obtain angiotensin converting enzyme (ACE) with high specific activity and to evaluate the ability to maintain enzyme activity in extract products as well as in rabbit lungs using frozen condition. In the scope of the content, the study conducted an evaluation to select the appropriate extraction solvent of four solvents including acetone, ethanol, Tris- $\mathrm{HCl}$ and distilled water. Initially, the research results have helped determine distilled water as the suitable extraction solvent and the difference is not statistically significant compared to Tris- $\mathrm{HCl}$ solvent. Angiotensin converting enzyme extract that was obtained by distilled water solvent has a specific activity of $10.35 \mathrm{U} / \mathrm{g}$ protein. In addition, the study investigated the ability to maintain angiotensin converting enzyme activity in rabbit lung and crude enzyme product during frozen storage $\left(-18 \pm 2^{\circ} \mathrm{C}\right)$. The results of the study showed that angiotensin converting enzyme activity could be maintained for 3 months in rabbit lungs and 4 months in the crude product. Besides, the study also used ammonium sulfate with different concentrations to conduct angiotensin converting enzyme collection from extract product. The results of this content help determine the use of saturated ammonium sulfate with concentrations of $50 \%$ to $60 \%$ for the highest efficiency. The precipitation process helped obtain ACE products with a purity of 4.22 times, the specific activity of $42.64 \mathrm{U} / \mathrm{g}$ protein and the recovery rate of ACE up to $29.37 \%$.
\end{abstract}

\section{Introduction}

Enzymes play an important role in scientific research as well as in medicine and food processing. The technology in enzyme production has brought significant profits to many countries, production and sales of enzymes in the world market increased by $20-30 \%$ per year (Murado et al., 2009). In recent years, the technology of producing enzymes such as protease, lipase and cellulase has been studied widely, to the point of being easily extracted. Nowadays, angiotensin converting enzyme (ACE, peptidyl dipeptide hydrolase, EC 3.4.15.1) is increasingly interested in studies of hypertension. This is an enzyme that plays an important role in regulating blood pressure through the Renin Angiotensin Aldosterone system (Muñoz-Durango et al., 2016). In Vietnam, the use of this enzyme for research is very limited due to the high cost and the difficulty of finding on the market. Studies of ACE extract from the lungs of mammals have also been conducted in various studies, and in many countries around the world (Shafiee et al., 2005; Abdulazeez and Kurfi, 2016). In 1971, Cushman and Cheung showed that the lung tissue of mammals (especially rabbit lungs) contained ACE with high activity. On the other hand, rabbit lung is a byproduct in rabbit processing with low economic value. All of this shows the potential to use rabbit lungs as a cheap ACE supply for research. Therefore, the study was conducted to obtain ACE with high specific activity and to evaluate the ability to maintain enzyme activity in extract products as well as in rabbit lungs using frozen condition.

\section{Materials and methods}

The research was conducted at the Laboratory of Food Technology, Faculty of Agriculture, Can Tho University. Major equipment and chemicals used in the study include Thermo Multiskan Spectrum Reader (USA), Cold centrifuge (HermLe Labortechnik GmbH 
Siemensstr., Type: Z232K, Germany), Micropipet (EMC Lab), N-[3-(2-Furyl)acryloyl]-Phe-Gly-Gly (SigmaAldrich), Tris- $\mathrm{HCl}$ (Merck), Ammonium sulfate (China).

Rabbit lungs are selected from healthy male crossbred rabbits (New Zealand x local) were purchased directly from the farming area in Vinh Long province, Vietnam, with a weight range 3.5 to $4 \mathrm{~kg}$. The lungs were collected immediately after slaughter and kept cold afterwards. After collection, lungs were washing, separating bronchial and fat and keeping in polyamide (PA) packaging at frozen condition $\left(-18 \pm 2^{\circ} \mathrm{C}\right)$ before further processing.

\subsection{Research procedures}

Frozen rabbit lungs were finely cut about 3 mins in cold condition before extraction. In the study, the investigation of ACE extraction by 4 solvents was conducted (Experiment 1) using the ratio of lung and solvent is 1:2 (Abdulazeez and Kurfi, 2016; Gupta et al., 2018). All solvents were cooled to $4 \pm 2^{\circ} \mathrm{C}$ before conducting the study. Acetone and ethanol were added slowly at grinding time. If the extraction solvent was water or Tris- $\mathrm{HCl}$, the supernatant after centrifugation $\left(10,000 \times g, 30\right.$ mins, $\left.4^{\circ} \mathrm{C}\right)$ would be recovered, filtered and adjusted to a fixed volume to obtain crude ACE. On the contrary, the residue would be the main component of the extraction process if the extraction solvent was acetone or ethanol. The centrifugal residue after solvent removal was dissolved in Tris- $\mathrm{HCl}$ and centrifuged again to extract raw ACE. Analyze the activity indicators of crude ACE to determine the appropriate extraction solvent. To assess the possibility of maintaining ACE activity in freezing conditions, frozen storage experiments were also carried out for rabbit lungs contained in Falcon $15 \mathrm{~mL}$ and crude ACE contained in Falcon $15 \mathrm{~mL}$ (Experiment 2). Storage temperature was fixed at $-18 \pm 2{ }^{\circ} \mathrm{C}$ and sample analysis was expected after each month of storage. In the other hand, the study also used cold ammonium sulfate with different concentrations (from $30 \%$ to $70 \%$ saturated concentration) to collection ACE (Mansurah et al., 2013) (Experiment 3). The addition of ammonium sulfate was carried out by magnetic stirring and the mixture was kept cold by ice. After dissolving the salt completely, leave the mixture in the refrigerator for $1 \mathrm{hr}$ before centrifuging to obtain a residue. The centrifugal residue would be dialyzed by cellophane membrane in the solvent which is a result of Experiment 1 to remove ammonium sulfate out of ACE. The activity indicators of the product would be analyzed as a basis for selecting the appropriate salt concentration. The result of Experiment 1 was chosen as a fixed factor for Experiment 2 and Experiment 3.
Experiment 1. Investigated the ACE extraction ability of different solvents in four solvents of distilled water, $50 \mathrm{mM}$ Tris- $\mathrm{HCl} \mathrm{pH} 8.3$ containing $30 \mathrm{mM} \mathrm{NaCl}$, acetone and ethanol.

Experiment 2. Evaluated the ability to maintain ACE activity in rabbit lungs and crude enzyme product in frozen storage $\left(-18 \pm 2^{\circ} \mathrm{C}\right)$.

Experiment 3. Investigated the efficiency to collect ACE of ammonium sulfate with different concentrations (from $30 \%$ to $70 \%$ saturated concentration).

\subsection{Proximate analysis}

The proximate analysis was determined according to AOAC methods (AOAC, 1995). Moisture content was determined by AOAC 925.04, protein content was determined by the Kjeldahl method (AOAC 981.10) and lipid content was determined by Soxhlet method (AOAC 920.39). ACE activity (U/L) was analyzed based on the method of Restrepo et al. (2013). Specific activity was determined based on the amount of protein (Ngo et al., 2008). Molecular weight was analyzed by SDS - PAGE.

\subsection{Data analysis}

Using Statgraphics Centurion XVII.II program, data were analyzed for the degree of variation and significance of difference based on the analysis of variance (ANOVA) to determine if significant differences $(p \leq 0.05)$ existed between treatments using Least Significant Difference (LSD) or Duncan test. All experiments were carried out in triplicate.

\section{Results and discussion}

\subsection{Physical and chemical properties of rabbit lung}

Healthy male crossbred rabbits in Vinh Long province were used to get lungs as raw material for all experiments. The angiotensin converting enzyme is a protein component of rabbit lungs, so ACE extraction from rabbit lungs is influenced by the physicochemical properties of the lungs. At the same time, the basic physicochemical properties of rabbit lung is needed to determine the uniformity of the source of raw materials for research. The results of basic physicochemical composition analysis of rabbit lung showed in Table 1.

Table 1. Chemical and physical properties of crossbred rabbit lung

\begin{tabular}{cc}
\hline Proximate parameters & Value \\
\hline Moisture (\%) & $81.89 \pm 1.24$ \\
Protein (\%) & $13.45 \pm 0.28$ \\
Lipid (\%) & $2.74 \pm 0.09$ \\
pH & $6.54 \pm 0.03$ \\
\hline
\end{tabular}


The determination of the physical and chemical components of the material is necessary because the study of Kutrovic (2011) has shown that the enzyme activity in the final product depends greatly on the composition of the material. In particular, the presence of protein, fat, $\mathrm{pH}$ and fatty acid components have a great influence on enzyme collection efficiency. In addition, the extraction process is also governed by moisture content. The origin of enzymes is proteins; the results in Table 1 showed that rabbit lungs were a source of protein with relatively high protein content (13.45\%). Many studies have demonstrated a high activity of ACE receptor from rabbit lungs, so the research resource (crossbred rabbit lung) had a high potential for ACE recovery (Cushman and Cheung, 1971; Shafiee et al., 2005; Mansurah et al., 2013). Lipid content in the rabbit lung was negligible $(2.74 \%)$, which would be removed through low-temperature centrifugation and filtration. Moisture content and $\mathrm{pH}$ of $81.89 \%$ and $\mathrm{pH} 6.54$ respectively would be an important basis to calculate the extraction, storage and purification process of ACE. High protein and moisture content will have negative impacts on the stability of ACE in lung rabbits, especially in inappropriate conditions. Therefore, it is necessary to keep the rabbit lung in low temperature conditions. In addition, with a standard deviation of less than $2 \%$ at all analytical criteria of the raw material, it has been shown that homogeneity of research materials has been ensured, Figure 1 also helped confirm this.

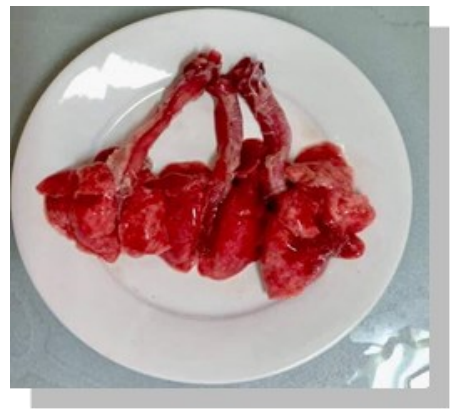

Figure 1. Raw crossbred rabbit lungs

\subsection{ACE extraction capability of different solvents}

Enzymes are biological catalysts obtained mainly by extraction from animals, plants or microorganisms. In the study, crossbred rabbit lungs were used to perform extraction of ACE with four solvents including distilled water, Tris- $\mathrm{HCl}$, acetone and ethanol. The results of ACE extraction were shown in Figure 2 and Table 2.

The results in Figure 2 showed that the use of Tris$\mathrm{HCl}$ or distilled water to extract ACE from rabbit lungs would help to obtain a high protein product. The extract products of rabbit lungs by Tris- $\mathrm{HCl}$ and distilled water had a protein content of $4.14 \%$ and $3.85 \%$, respectively. Meanwhile, the extract products after making precipitation by acetone or ethanol had lower protein content. This may be explained by the fact that precipitation by organic solvents reduced the solubility of the protein in the rabbit lungs so that the protein content of the extract was low. However, in order to determine the extraction efficiency of solvents, it was also necessary to consider the specific activity of the extract.

The analytical results in Figure 2 and Table 2 showed that the ACE activity and protein content of extracted products by four solvents (acetone, ethanol, distilled water and Tris- $\mathrm{HCl}$ ) had the same variation rules. High ACE activity obtained when the protein content of extract products was high. Table 2 showed the highest ACE activity of the product that used Tris- $\mathrm{HCl}$ or distilled water to extract. The difference in enzyme activity extracted by Tris- $\mathrm{HCl}$ or distilled water was not significant, respectively 408.83 (U/L) and 398.57 (U/L). The results were also consistent with the research of Mansurah et al. (2013) and Abdulazeez and Kurfi (2016), using sodium and Tris- $\mathrm{HCl}$ buffer solvent to extract ACE from rat lung and rabbit lung.

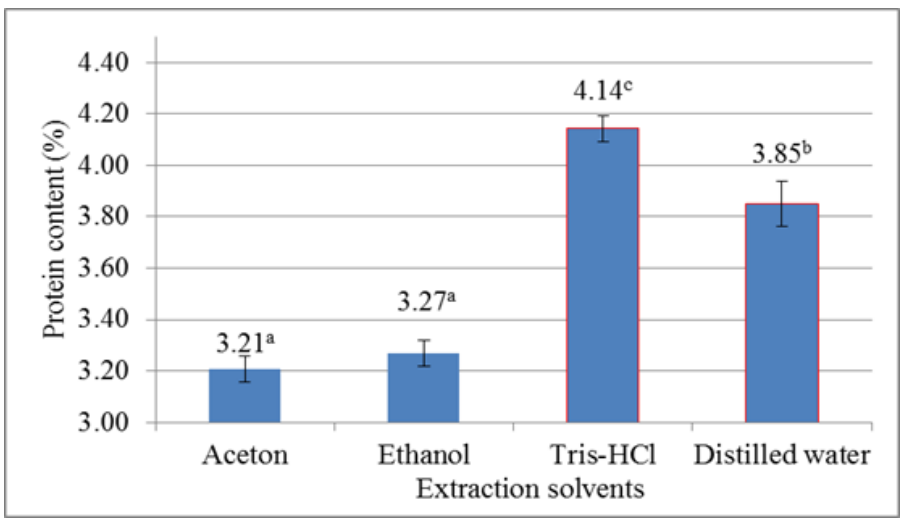

Figure 2. Protein content in products extracted by different solvents. Different letters in the column indicate significant differences in the test treatments at $95 \%$ confidence intervals.

Table 2. Specific activity and activity of the product extracted by different solvents

\begin{tabular}{ccc}
\hline Solvent & Activity $(\mathrm{U} / \mathrm{L})$ & Specific activity $(\mathrm{U} / \mathrm{g}$ protein) \\
\hline Acetone & $53.53 \pm 9.36^{\mathrm{b}}$ & $1.67 \pm 0.27^{\mathrm{b}}$ \\
Ethanol & $12.47 \pm 10.22^{\mathrm{a}}$ & $0.38 \pm 0.31^{\mathrm{a}}$ \\
Distilled water & $398.57 \pm 14.65^{\mathrm{c}}$ & $10.35 \pm 0.28^{\mathrm{c}}$ \\
Tris-HCl & $408.83 \pm 17.05^{\mathrm{c}}$ & $9.87 \pm 0.35^{\mathrm{c}}$ \\
\hline
\end{tabular}

Different letters in the column indicate significant differences in the test treatments at $95 \%$ confidence intervals.

From the above results, it can be confirmed, distilled water and Tris- $\mathrm{HCl}$ gave much higher ACE extraction efficiency when compared with extraction with acetone and ethanol solvent. In addition, the difference in extraction efficiency of Tris- $\mathrm{HCl}$ and distilled water was not statistically significant, so distilled water could be 
selected as a more efficient extraction of ACE by reducing cost and limiting the use of chemical ingredients in extract.

The extraction of ACE from crossbred rabbit lung with distilled water (Figure 3) obtained high activity and specific activity, respectively, $398.57 \mathrm{U} / \mathrm{L}$ and $10.35 \mathrm{U} / \mathrm{g}$ protein. However, research by Mansurah et al. (2013) gave higher extraction efficiencies compared to this research (specific activity of extract products reached 49 $\mathrm{U} / \mathrm{g}$ protein). This difference may be due to the source of rabbit lung used in the study. The obtained ACE was still in its raw form (crude ACE) with low activity and there were still some other protein components (Sallau et al., 2008), so the use of ammonium sulfate to carry out the process partial purification should be conducted to obtain enzymes with higher purity.

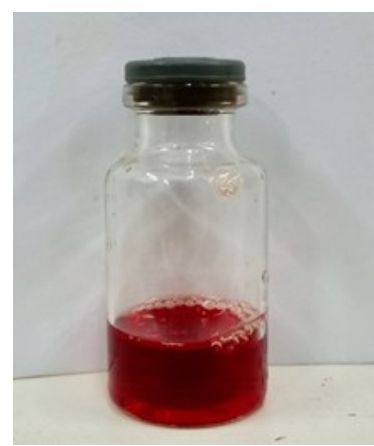

Figure 3. Crude ACE

\subsection{The effect of frozen storage on changes in $A C E$ activity in rabbit lungs and crude ACE}

Frozen storage is a solution to inhibit biological processes or the growth of microorganisms in products, which have been used in maintaining a stable source of materials for this research. In addition, the freezing process is a pre-treatment method that makes grinding and extracting easy. However, a problem is the degradation of enzyme activity due to the formation of ice crystals in frozen products. The results of the ability to maintain ACE activity in the rabbit lungs and the raw ACE during frozen storage are shown in Figure 4.

Survey results showed that ACE activity of control samples for rabbit lungs and crude ACE were almost the same. The formation of ice crystals during freezing was a factor that had an adverse effect on protein structure as well as enzyme activity. However, Figure 4 shows that this effect was negligible and ACE activity was reduced after 24 hours of freezing but this difference is not significant. In addition, ACE stability in rabbit lungs could also be maintained up to 3 months of storage and up to 5 months for extract products. The decrease in enzyme activity during frozen storage was explained by the effect of temperature fluctuations affecting the tissue structure (Asgeirsson et al., 1995). Figure 4 also shows that the structural components inside the rabbit lungs may have changed drastically after slaughter and storage. This transformation had an effect on ACE, which had rapidly lost ACE activity that existed within the lung structure.

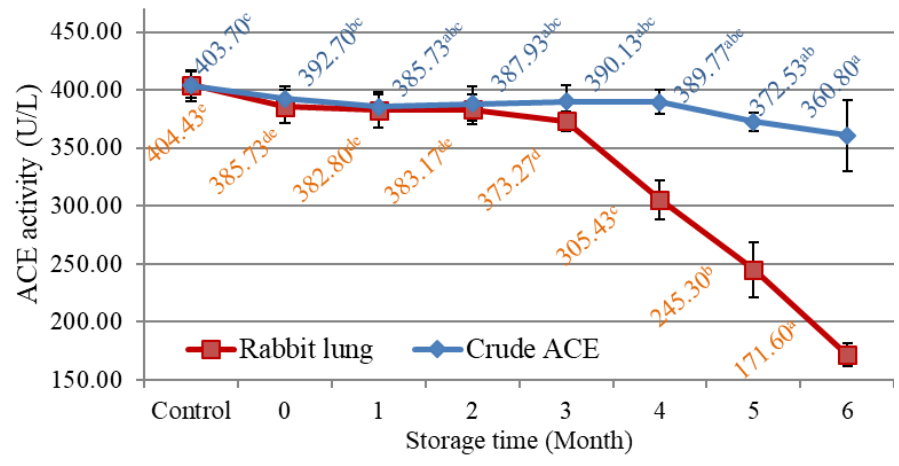

Figure 4. Changes in ACE activity during frozen storage of rabbit lungs and crude $\mathrm{ACE}$

From the above results, it is not appropriate to storage ACE by freezing rabbit lungs, at $-18 \pm 2^{\circ} \mathrm{C}$ only can maintain ACE activity for 3 months of storage. This change was also reflected in the appearance of the lung (Figure 5), the discoloration has begun to occur in the 5th month of storage and become worse after 6 months of storage. Although it is only an extract product, crude ACE showed a better ability to maintain activity than the lung (Figure 4). After 6 months of frozen storage, the activity of crude ACE did not change much when compared with storage rabbit lungs. In the first 5 months, the difference in ACE activity was not statistically significant.

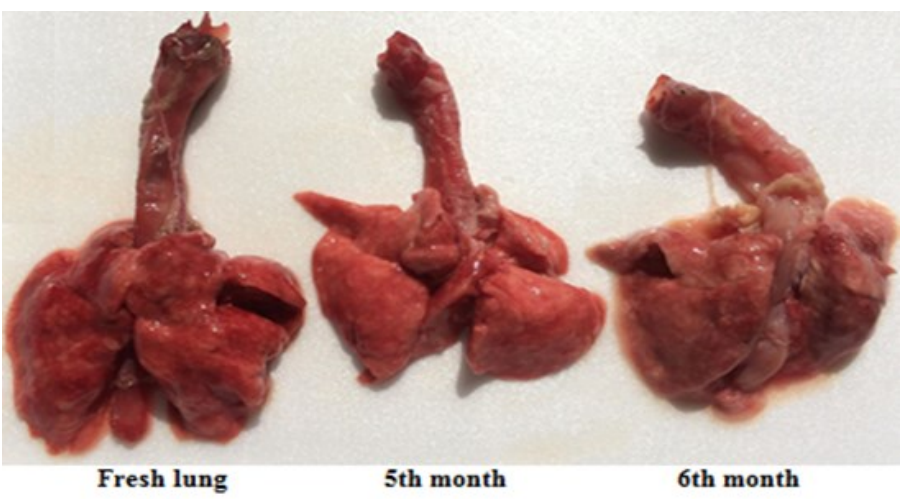

Figure 5. The appearance changes of rabbit lungs after frozen storage

Achieving activity stability as a result of the experiment may be due to the fact that extraction had eliminated some components that interact with ACE in the product. Elimination of other components will help ACE maintain better activity during frozen storage (Sallau et al., 2008).

In short, rabbit lungs can only be stored until the 3rd month while crude ACE can extend storage until the 5th month that the activity was maintained. The ACE 
activity decline of the extract in the 6th month of storage was still not much.

\subsection{The efficiency of ACE collection by ammonium sulfate}

In crude enzyme extracts, the presence of proteins that were not enzymes and other components of the cell has made the enzyme's specific activity low. To remove these unwanted components, we often use protein precipitation methods based on their solubility. In precipitation agents, ammonium sulfate has been widely used in enzymatic partial purification studies in laboratories and also in industrial scale production due to the effective precipitation and maintenance of enzyme activity (Scopes, 1994), and the solubility is large as well as the effect of temperature on its solubility is not available (Dixon and Webb, 1964). In the scope of the study, ACE precipitation was performed by the different saturated concentration of ammonium sulfate to find the appropriate concentration in ACE collection, the survey results were shown in Table 3.

At the different concentration of salt supplementation, the protein content of the product was different. The addition of salt to $30 \%$ would help to achieve the highest protein yield, this value would be reduced to the lowest at $60-70 \%$ salt concentration. However, the enzyme activity did not depend on protein yield, making specific activity also varies (Table 3 ). This made it possible to find a saturated salt concentration in which the appropriate protein component precipitates.

The results of Table 3 showed that the precipitation by ammonium sulfate helped to collect higher purity enzyme, which was shown in increasing specific activity at different salt concentrations, this was the initial step for the purification process at a higher level. Although the protein content was high when precipitation was at $30 \%$ saturation of ammonium sulfate, the specific activity of the product was low. In contrast, precipitation in the 50 to $60 \%$ ammonium sulfate fraction received low protein content but had a very high specific activity, which was 3 times higher than the $30 \%$ precipitate. The increase in specific activity after precipitation may be due to the removal of components that cause synergistic interactions in the lungs (Sallau et al., 2008). The ACEactive peptides would precipitate at certain concentrations of amonium sulfate, which makes it easy to collect ACE. However, there was still a significant amounts of peptides similar to ACE and reduced the activity of extract product. Both protein content and specific activity decreased at higher concentration (60$70 \%$ ), indicating that the remaining protein content after precipitation of $50-60 \%$ was not much and enzyme activity was not high. Therefore, angiotensin converting enzymes may be peptides that are susceptible to precipitation in the fraction of $50-60 \%$ saturated ammonium sulfate. The research results are similar to those of Shafiee et al. (2005), using a saturation concentration of $50 \%$ to $70 \%$ of ammonium sulfate to preliminary purify ACE from rabbit lungs. In addition, ACE yield of different precipitation concentrations should also be considered. Research results Table 3 showed that different precipitation fractions yielded different ACE, the highest yield efficiency was in the precipitation fraction $50-60 \%$ saturated ammonium sulfate $(29.37 \%)$ and $28.01 \%$ ( $<30 \%$ saturated). But in terms of purity, the $50-60 \%$ saturated precipitated fraction had a purity of 4.22 , much higher than that of other fractions. This result was lower than that of Quassinti et al. (1998) and Mansurah et al. (2013), the results of these researches used saturated ammonium sulfate of $65 \%$ and $70 \%$, respectively, to collect the most active ACE. Abdulazeez and Kurfi (2016) also used 70\% saturated ammonium sulfate to obtain ACE from rat lungs, the specific activity obtained after dialysis was 50 $\mathrm{U} / \mathrm{g}$ protein. All of these differences are likely due to the actual conditions of the experiments and source of the material. ACE after partial purification was analyzed by SDS - PAGE to determine the molecular weight, the results were shown in Figure 6.

Figure 6 shows that the $40-50 \%$ fraction contained many protein components with different molecular weight compared to $50-60 \%$ fraction. Moreover, the results in Table 3 showed that the fraction of $50-60 \%$ saturated ammonium sulfate had the highest specific activity. Therefore, it can be concluded that $50-60 \%$

Table 3. Basic parameters of ACE collection efficiency by ammonium sulfate

\begin{tabular}{cccccc}
\hline Concentration (\%) & Protein (\%) & Total activity (U/L) & Specific activity (U/g protein) & Purity & Yield (\%) \\
\hline Control & $3.94 \pm 0.09^{\mathrm{d}}$ & $397.83 \pm 2.29^{\mathrm{c}}$ & $10.11 \pm 0.22^{\mathrm{a}}$ & 1 & 100 \\
$<30$ & $8.61 \pm 0.05^{\mathrm{e}}$ & $1114.30 \pm 27.89^{\mathrm{e}}$ & $12.95 \pm 0.36^{\mathrm{a}}$ & 1.28 & 28.01 \\
$30-40$ & $1.93 \pm 0.09^{\mathrm{b}}$ & $316.80 \pm 25.16^{\mathrm{b}}$ & $16.49 \pm 1.66^{\mathrm{b}}$ & 1.63 & 7.96 \\
$40-50$ & $2.01 \pm 0.09^{\mathrm{b}}$ & $480.70 \pm 33.89^{\mathrm{d}}$ & $23.95 \pm 2.52^{\mathrm{c}}$ & 2.37 & 12.08 \\
$50-60$ & $2.74 \pm 0.05^{\mathrm{c}}$ & $1168.57 \pm 14.65^{\mathrm{f}}$ & $42.64 \pm 1.22^{\mathrm{d}}$ & 4.22 & 29.37 \\
$60-70$ & $0.91 \pm 0.05^{\mathrm{a}}$ & $209.367 \pm 17.78^{\mathrm{a}}$ & $23.19 \pm 2.24^{\mathrm{c}}$ & 2.29 & 5.26 \\
\hline
\end{tabular}

Different letters in the column indicate significant differences in the test treatments at $95 \%$ confidence intervals 
fractions contain low levels of impurity proteins, which helps to reduce the synergistic interactions in the product, thus increasing the specific activity of the product. This has also been demonstrated in the research of Sallau et al. (2008). The result of Figure 6 also showed that the molecular weight of ACE was distributed around the line of $66.2 \mathrm{kDa}$. Therefore, the extraction and partial purification collected low molecular weight angiotensin converting enzyme (65 to $68 \mathrm{kDa}$ ) with amino terminal (N-terminal domain ACE). This kind of enzyme has also been found in studies of Deddish et al. (1994), Casarini et al. (1995) and Deddish et al. (1996).

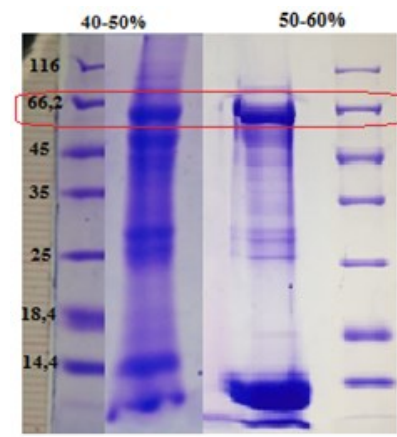

Figure 6 . The result of molecular weight analysis of fractions $40-50 \%$ and $50-60 \%$

\section{Conclusion}

The research results have helped to obtain highly active ACE from crossbred rabbit lungs for hypertension research. The use of distilled water has brought high extraction efficiency, the specific activity after extraction was 10.35 (U/g protein). The results of frozen storage at $-18 \pm 2^{\circ} \mathrm{C}$ showed that the ability to maintain $\mathrm{ACE}$ activity in rabbit lungs and crude ACE were 3 months and 5 months, respectively. The partially purified ACE by $50-60 \%$ saturated ammonium sulfate had a specific activity of $42.64 \mathrm{U} / \mathrm{g}$ protein corresponding to a purity of 4.22 times and a yield of $29.37 \%$. The molecular weight of the product was about $66.2 \mathrm{kDa}$.

\section{Conflict of Interest}

The authors declare no conflicts of interest.

\section{Acknowledgments}

The authors acknowledge Can Tho University in providing facilities for the smooth running of this study.

\section{References}

AOAC. (1995). Official methods of analysis of AOAC international. 15th ed. Washington, DC: Association of Official Analytical Chemists.

Abdulazeez, M.A. and Kurfi, B.G. (2016). Isolation, partial purification and characterization of angiotensin converting enzyme from rat (Rattus norvegicus) lungs. Bayero Journal of Pure and Applied Sciences, 9(2), 24-29. https:// doi.org/10.4314/bajopas.v9i2.5

Asgeirsson, B., Hartemink, R. and Chlebowski, J.F. (1995). Alkaline phosphatase from Atlantic cod (Gadus morhua)-Kinetic and structural properties which indicator adaptation to low temperatures. Comparative Biochemistry and Physiology, 110(2), 315-329. https://doi.org/10.1016/0305-0491(94) 00171-P

Casarini, D.E., Carmona, A.K., Plavinik, F.L., Juliano, L., Zanella, M.T. and Ribeiro, A.B. (1995). Effects of calcium blockers as inhibitors of angiotensin Iconverting enzyme. Hypertension, 26, 1145-1148. https://doi.org/10.1161/01.HYP.26.6.1145

Cushman, D.W. and Cheung, H.S. (1971). Spectrophotometric assay and properties of the angiotensin -converting enzyme of rabbit lung. Biochemical Pharmacology, 20(7), 1637-1648. https://doi.org/10.1016/0006-2952(71)90292-9

Deddish, P.A., Wang, J., Michel, B., Morris, P.W., Davidson, N.O., Skidgel, R.A. and Erdös, E.G. (1994). Naturally occurring active N-domain of human angiotensin I-converting enzyme. Proceedings of the National Academy of Sciences of the United States of America, 91, 7807-7811. https:// doi.org/10.1073/pnas.91.16.7807

Deddish, P.A., Wang, L., Jackman, H.L., Michel, B., Wang, J., Skidgel, R.A. and Erdös, E.G. (1996). Single domain angiotensin I converting enzyme (kininase II): characteristics and properties. Journal of Pharmacology and Experimental Therapeutics, 279(3), 1582-1589.

Dixon, M. and Webb, E.C. (1964). Enzyme. $2^{\text {nd }}$ Ed. New York: Academic Press.

Gupta, N., Srivastava, N. and Bhagyawant, S.S. (2018). Vicilin-A major storage protein of mungbean exhibits antioxidative potential, antiproliferative effects and ACE inhibitory activity. PLoS One, 13 (2), e0191265. https://doi.org/10.1371/ journal.pone. 0191265

Kutrovic, I., Marshall, S.N. and Zhao, X. (2011). Hydrophobic immobilization of a bile salt activated lipase from Chinook salmon (Oncorhynchus tshawytscha). Journal of Molecular Catalysis B: Enzymatic, $72 \quad$ (3-4), 168-174. https:// doi.org/10.1016/j.molcatb.2011.06.001

Muñoz-Durango, N., Fuentes, C.A., Castillo, A.E., González-Gómez, L.M., Vecchiola, A., Fardella, C.E. and Kalergis, A.M. (2016). Role of the Renin- 
Angiotensin-Aldosterone System beyond Blood

Pressure Regulation: Molecular and Cellular Mechanisms Involved in End-Organ Damage during Arterial Hypertension. International Journal of Molecular Sciences, 17(7), 797. https:// doi.org/10.3390/ijms 17070797

Murado, M.A., González, M.P. and Vázquez, J.A. (2009). Recovery of proteolytic and collagenolytic activities from viscera by-products of rayfish (Raja clavata). Marine Drugs, 7(4), 803-815. https:// doi.org/10.3390/md7040803

Ngo, L.T.A., Pham, T.L. and Le, V.V.M. (2008). Purification of Endopolygalacturonase from Submerged Culture of Aspergillus awamori L1 Using a Two-step Procedure: Enzyme Precipitation and Gel Filtration. International Food Research Journal, 15(2), 135-140.

Quassinti, L., Miano, A., Bramucci, M., Maccari, E. and Amici, D. (1998). Purification of swine serum angiotensin converting enzyme with high recovery of activity using lisinopril coupled to epoxyactivated sepharose 6B. International Union of Biochemistry and Molecular Biology Life, 44(5), 887 -889. https://doi.org/10.1080/15216549800201942

Restrepo, R.A., Loango, N., Moncada, M.V. and Landazuri, P. (2013). Angiotensin-converting enzyme inhibitory activity of Passiflora edulis $\mathrm{f}$. flavicarpa and Petroselinum crispum (mill) fuss. British Journal of Pharmaceutical Research, 3(4), 776-785. https://doi.org/10.9734/BJPR/2013/3517

Sallau, A.B., Ibrahim, M.A., Salihu, A. and Patrick, F.U. (2008). Characterization of phospholipase A2 from Echis ocellatus venom. African Journal of Biochemistry Research, 2, 98-101.

Scopes, R.K. (1994). Protein purification, principle and practice. $3^{\text {rd }}$ ed. New York: Springer-Verlag. https:// doi.org/10.1007/978-1-4757-2333-5

Shafiee, S.M., Keyhani, M., Shabani, M., Koochaki Shalmani, I. and Kaviani, M. (2005). Extraction and Development of Multi-Step Purification of Angiotensin-I Converting Enzyme (ACE) from Rabbit Lung. Razi Journal of Medical Sciences, 11 (44), 979-985. 